\title{
Analisis Kinerja Web Server pada SIM Manajemen Diklat Poltekpel Sorong Menggunakan RDBMS MySQL dan MariaDB
}

\author{
Jeffry \\ Fakultas Matematika dan Ilmu Pengetahuan Alam \\ Universitas Pancasakti \\ Makassar, Indonesia \\ jeffry@unpacti.ac.id
}

\begin{abstract}
Abstrak
Abstrak Perkembangan teknologi informasi dan data meningkat pesat di era big data seperti sekarang ini. Database Management System menjadi bagian utama yang sangat penting untuk mengontrol arus data. Penelitian ini membandingkan kinerja web server yang menggunakan RDBMS open source yang berbeda antara MySQL dan MariaDB. Pengujian dilakukan pada Oracle Virtual Machine Virtualbox menggunakan ApacheBench untuk mengukur kinerja Web Server pada SIM Manajemen Diklat Poltekpel Sorong. Hasil percobaan menunjukkan bahwa web server ketika menggunakan RDBMS MySQL cenderung memiliki performa yang cukup stabil ketika permintaan akses web di bawah 300 kali secara bersamaan yaitu pada 100,200 dan 300 kali berturut-turut sebesar $7.764 / \mathrm{ms}, 16.386 / \mathrm{ms}$ dan $30.025 / \mathrm{ms}$. Namun, saat permintaan akses web di atas 300 secara bersamaan RDBMS MariaDB justru menunjukkan kinerja yang lebih baik. Hal ini ditunjukkan dengan permintaan akses 400 dan 500 kali web server secara bersamaan, waktu respon terlihat lebih cepat dibandingkan ketika menggunakan RDBMS MySQL berturut-turut sebesar 51.877/ms dan 54.702/ms sedangkan RDBMS mariaDB untuk permintaan akses web server secara bersamaan pada 100,200,300,400 dan 500 berturut-turut sebesar $14.213 / \mathrm{ms}, 25.642 / \mathrm{ms}, 40.831 / \mathrm{ms}, 48.021 / \mathrm{ms}$ dan $51.630 / \mathrm{ms}$.
\end{abstract}

Kata Kunci: SIM, Database, DBMS, MySQL, MariaDB.

\begin{abstract}
Abstract The development of information and data technology has increased rapidly in the era of big data as it is today. The Database of Management System becomes the most important main part to control the flow of data. This research compares the performance of web servers using different open source RDBMS between MYSQL and MariaDB. This research was conducted on Oracle Virtual Machine VirtualBox by using ApacheBench to measure Web Server performance on SIM Management Training of Poltekpel Sorong. The results of this research showed that web servers when using RDBMS MySQL tend to have stable enough performance when web access requests are below 300 times simultaneously, namely at 100,200 and 300 times respectively at 7.764/ms, 16.386/ms and 30.025/Ms. However, when requesting of web access is above 300 simultaneously, RDBMS MariaDB actually shows better performance. This is indicated by access requests 400 and 500 times web server simultaneously, the response time looks faster than when using RDBMS MySQL respectively at 51.877/ms and 54.702/ms while RDBMS MariaDB for requesting of web server access simultaneously at 100,200, 300, 400 and 500 respectively at $14.213 / \mathrm{ms}, 25.642 / \mathrm{ms}, 40.831 / \mathrm{ms}, 48.021 / \mathrm{ms}$ and $51.630 / \mathrm{ms}$.
\end{abstract}

Keywords: $\quad$ SIM, Database, DBMS, MySQL, MariaDB. 


\section{Pendahuluan}

Aliran data yang besar menjadikan Relation Database Management System (RDBMS) menjadi alat yang sangat penting dan populer untuk ketahanan data. Perkembangan arus informasi dan meningkatnya permintaan akan data berbanding lurus dengan manajemen serta pembuatan informasi data seperti pengolahan data dalam bidang medis, militer, media sosial dan data bisnis. Hal ini menyebabkan para pengembang program berlomba-lomba membuat program manajemen database, baik itu yang berbayar maupun open source seperti Oracle, PostgreSQL, MySQL, MariaDB, Microsoft SQL Server, SQLite, dll.

Saat ini, aplikasi RDBMS open source memiliki popularitas yang tidak kalah dengan aplikasi RDBMS berbayar. Bahkan banyak perusahan yang membangun sebuah website dengan memanfaatkan aplikasi RDBMS open source. Suatu website harus memperhatikan waktu pemuatan halaman dan database secara langsung karena berdampak pada produk bisnis terkait. Menurut (Dawodi et al., 2019) aplikasi RDBMS open source yang sangat populer adalah MySQL yang merupakan penyedia layanan hosting seperti Rackspace, GoDaddy, Bluehost, WHM, dll. Penelitian (Ongo \& Kusuma, 2018) menyebutkan bahwa MySQL merupakan media penyimpanan data yang paling banyak digunakan untuk aplikasi berbasis website karena kecepatannya dalam membaca data. Selain itu, rendahnya biaya implementasi pengerjaan proyek karena bersifat open source. Namun, MySQL kini diakuisisi oleh Oracle Sphinx Technologies Inc (20012015) dan kemudian muncul MariaDB dengan versi yang lebih baru. Disaat bersamaan, MariaDB berkembang bersamaan dengan MySQL yang dikelola oleh Oracle (Tongkaw \& Tongkaw, 2016).

Hal ini sangat menarik untuk dilakukan penelitian dengan mengukur kinerja Web server yang menggunakan RDBMS MySQL dan MariaDB pada kondisi yang sebenarnya. Penelitian (Tongkaw \& Tongkaw, 2016) mengukur kinerja MySQL dan MariaDB yang dilakukan pada Xen 4.4 Virtual Machine menggunakan OLTP-Simple dan OLTP-Seats sebagai data benchmark. Hasil penelitian menunjukkan bahwa MySQL memiliki performa yang lebih baik dibandingkan MariaDB. Penelitian (Warman \& Ramdaniansyah, 2018) melakukan pengujian kinerja query DML (Data Manipulation Language), Agregat fungsi, dan operator penghubung antara database MySQL dan MariaDB. Hasil penelitian menunjukkan bahwa MySQL memiliki keunggulan kecepatan waktu dibanding MariaDB pada pengujian stored procedure. Sedangkan pada pengujian Trigger Event Insert dan Update, MariaDB lebih unggul dibandingkan dengan MySQL.

Penelitian (Dawodi et al., 2019) mengukur kinerja web server dengan mengusulkan dua metode pada MySQL untuk mengurangi waktu tunggu halaman website, yaitu dengan mengubah engine MySQL ke MyISAM dan mengubah buffer size pada konfigurasi MySQL. Hasil penelitian menunjukkan bahwa terjadi pengurangan yang signifikan pada waktu tunggu halaman website. Penelitian (Aditya \& Juhana, 2015) menggunakan MariaDB sebagai database server berbasis Open source MySQL dan melakukan Clustering database server menggunakan Galera Cluster yang merupakan implementasi multi master cluster untuk MySQL dan MariaDB dengan melakukan optimasi algoritma Weighted Round Robin. Hasil penelitian menunjukkan bahwa algoritma yang diusulkan dapat bekerja efektif pada environment yang dinamis yaitu internet. Penelitian (Fuad et al., 2014) melakukan analisis kinerja pada waktu processing MySQL Cluster, Hive, dan Pig. Hasil Penelitian menunjukkan bahwa Hive mampu menangani data besar dan lebih cepat dibanding MySQL Cluster pada mesin perangkat 
keras berbiaya rendah. Sementara Pig lebih cocok untuk query yang lebih kompleks dan kumpulan data yang lebih besar. Pada beberapa titik, query MySQL Cluster lebih cepat daripada Hive dan Pig. Tetapi ketika data semakin banyak, performa Hive bisa lebih kuat dari MySQL Cluster. Penelitian (Rafamantanantsoa \& Laha, 2018) melakukan analisis dan melakukan pemodelan menggunakan model Neural Network untuk mengetahui seberapa besar kinerja respon dari sebuah web server yang menggunakan database MySQL server dan PostgreSQL server. Hasil yang diperoleh bahwa untuk dua jenis server database yang digunakan, waktu respons rata-rata yang diamati untuk MySQL jauh lebih cepat daripada PostgreSQL hingga beberapa puluh milidetik. Namun untuk PostgreSQL, variasi waktu respons rata-rata dari web server ini lebih stabil. Penelitian (Saikia et al., 2015) melakukan analisis terhadap kinerja MySQL dan SQL Server dengan melihat waktu yang dibutuhkan saat menanggapi permintaan. Hasil menunjukkan bahwa SQL Server menunjukkan kinerja yang lebih baik dibanding MySQL dalam hal waktu respons. Dalam semua kasus uji, kecuali query INSERT, SQL Server secara konsisten membutuhkan waktu lebih sedikit bila dibandingkan dengan MySQL. MySQL juga berkinerja buruk dalam hal peningkatan data. MySQL menunjukkan peningkatan dua kali lipat dalam waktu yang diambil Ketika jumlah baris naik. SQL Server juga menunjukkan hal serupa, tetapi peningkatan waktu yang diambil tidak sebesar MySQL.

Penelitian ini disajikan untuk membandingkan kinerja RDBMS MySQL dan MariaDB untuk melihat seberapa besar pengaruh dari manajemen database terhadap waktu respon pada web server.

\section{Metodologi}

\subsection{Flowchart Penelitian}

Penelitian ini dimulai dengan membuat Sistem informasi dengan menggunakan dua jenis database server berbeda yaitu MySQL dan MariaDB, dengan studi kasus pada Manajemen Diklat Poltekpel Sorong. Aplikasi kemudian dieksekusi dan dilakukan pengukuran kinerja waktu respon masing-masing web server dengan database yang berbeda.

\subsection{MySQL}

MySQL adalah database SQL paling populer di komunitas open source dan digunakan hampir secara universal oleh situs web yang berjalan pada sistem open source. MySQL awalnya dikembangkan pada tahun 1994 dan secara resmi dirilis pada pertengahan 1995. Itu dibuat karena pencipta menganggap mSQL (berdasarkan ISAM) terlalu lambat dan tidak cukup fleksibel. Kemudian MySQL dibuat dengan antarmuka baru tetapi tetap menggunakan API yang sama dengan mSQL (Widenius et al., 2002). Bagian SQL dari "MySQL" adalah singkatan dari "Structured Query Language". SQL adalah bahasa standar yang paling umum digunakan untuk mengakses database. Bergantung pada lingkungan pemrograman, SQL dapat dimuat secara langsung (misalnya, untuk menghasilkan laporan), membuat query SQL ke dalam kode yang ditulis dalam bahasa lain, atau menggunakan API dengan menyembunyikan sintaks SQL (Pachev \& Pachev, 2007). MySQL diakuisisi oleh Sun Microsystems pada 2008, dan pada 2010 Oracle mengakuisisi Sun Microsystems. Pada hari yang sama Oracle membeli Sun Microsystems, salah satu pencipta asli MySQL pergi dan membawa banyak pengembang bersamanya untuk membuat sendiri dari MySQL yang disebut MariaDB. 
Vol. 1 No. 1 Juli 2020

Sifat open source MySQL (Watson et al., 2008) akhirnya mengarah pada kode sumbernya yang digunakan untuk pengembangan MariaDB.

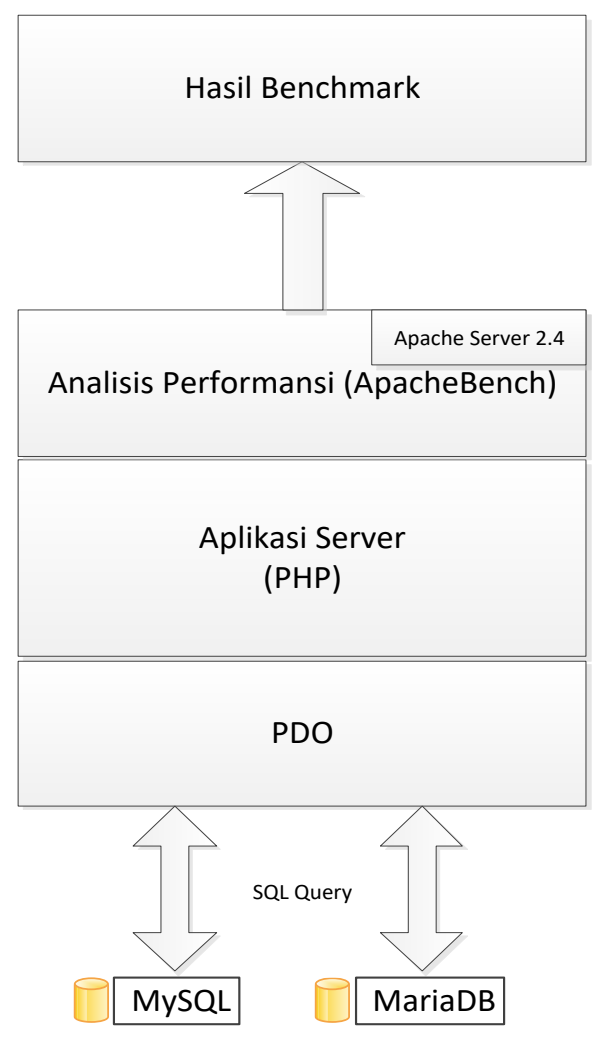

Gbr. 1. Flowchart Penelitian

\subsection{MariaDB}

MariaDB dirancang oleh mantan pengembang asli MySQL setelah terjadi akuisisi Oracle dari Sun Microsystems. Fitur utama dari MariaDB hampir sama dengan fitur pada MySQL. Para pengembang aplikasi tidak mengalami kesulitan yang nyata ketika melakukan migrasi dari MySQL ke MariaDB. Bahkan sebagian besar aplikasi untuk MySQL berfungsi dengan baik pada MariaDB tanpa memodifikasi apapun (Razzoli, 2014).

Seperti MySQL, MariaDB memuat beberapa database yang sudah ada yang digunakan oleh MariaDB sendiri untuk menyimpan metadata seperti informasi tentang basis data, tabel, kolom, pengguna, hak akses, log dan sebagainya (Sriparasa, 2014). MariaDB adalah MySQL dengan penambahan fungsionalitas baru, bahkan segala hal mulai dari baris perintah, dokumentasi dan lainnya masih bernama mysql (Forta, 2011).

\subsection{ApacheBench}

Analisis kinerja web server dapat dilakukan dengan menggunakan berbagai model atau alat. Beberapa pengukuran kinerja antara lain waktu respons di bawah file statis dan file dinamis, penggunaan memori, pemanfaatan pada beban pengguna dinamis dan variasi ukuran halaman web untuk jumlah pengguna yang berbeda. Salah satu alat yang bisa digunakan untuk mengukur kinerja web server adalah ApacheBench. ApacheBench 
adalah alat untuk mengukur kinerja (Benchmarking) HTTP Server (Kunda et al., 2017). Penelitian ini menggunakan ApacheBench untuk mengukur kinerja web server ketika melakukan permintaan data pada halaman website yang menggunakan RDBMS MySQL dan MariaDB.

\section{Eksperimental}

\subsection{Sumber Data}

Pada penelitian ini seluruh kegiatan dilakukan dengan melakukan pengamatan terhadap sistem yang dibangun dengan memperhatikan kebutuhan sistem yang diperlukan. Data diambil dari Politeknik Pelayaran Sorong (Poltekpel Sorong).

\subsection{Desain Sistem}

Penelitian ini menggunakan perangkat Lenovo Legion Y540 (Intel Core i5-9300H CPU @ 2.40GHz, 2.4GHz RAM 8GB) dengan membuat virtual mesin pada Oracle VM Virtual Box 6.1 dimana komputer yang dibuat memiliki sistem operasi CentOS Linux Release 7.8.2003 (64-bit), RAM 6GB dengan beberapa fitur aplikasi yang telah terinstall didalamnya termasuk MariaDB 10.2.32 dan MySQL 5.7.30.

Pengujian dilakukan dengan mengukur kinerja web server menggunakan ApacheBench dengan melihat kinerja ketika menggunakan RDBMS MySQL dan MariaDB. Aplikasi web menggunakan Bahasa pemrograman PHP 7.2.31 (cli) menggunakan framework CodeIgniter 4. Sedangkan Apache 2.4.6 digunakan sebagai web server.

\subsection{Pengujian}

Pengujian dilakukan dengan benchmarking terhadap web server yang melakukan permintaan data terhadap program ketika dua RDBMS yang berbeda diterapkan yaitu MySQL dan MariaDB. Proses ini akan menghasilkan kesimpulan setelah melakukan perbandingan hasil benchmark dengan melihat waktu respon saat permintaan data pada kedua RDBMS.

\section{Hasil}

Pengujian dilakukan dengan benchmarking terhadap web server yang melakukan permintaan data ke RDBMS dalam hal ini MySQL dan MariaDB.

Tahap awal benchmarking pada web server di penelitian ini adalah dengan mengasumsikan 1.000 kali web server tersebut di akses, kemudian menentukan jumlah web server ketika diakses secara bersamaan.

Gambar 2 menunjukkan percobaan pertama yang dilakukan dengan menentukan 1.000 kali web server diakses dan 100 kali web server diakses secara bersamaan. Hasil percobaan menunjukan bahwa waktu respon web server mengalami peningkatan pada kedua RDBMS, namun web server yang menggunakan RDBMS MySQL memiliki kinerja yang lebih baik dibanding dengan MariaDB dengan waktu respon 7.764/ms untuk MySQL dan 14.213/ms untuk MariaDB pada akses web server yang ke 1.000. 


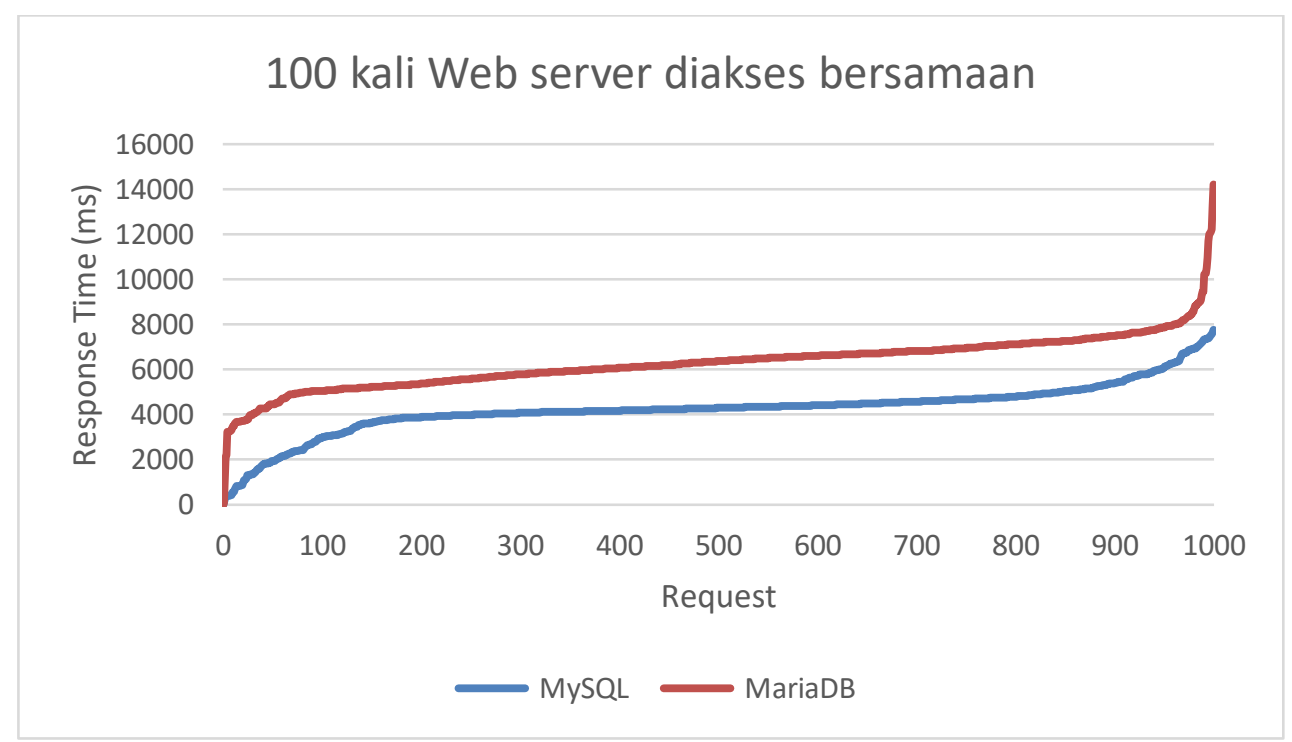

Gbr. 2. Kinerja Web Server 100 kali diakses bersamaan

Percobaan kedua dilakukan dengan 1.000 kali web server diakses dan 200 kali web server diakses secara bersamaan. Hasil percobaan dapat dilihat pada gambar 3 , dimana kinerja web server dengan menggunakan RDBMS MySQL masih terlihat lebih baik dibandingkan dengan menggunakan RDBMS MariaDB. Pada akses web server yang ke 1.000 dapat dilihat bahwa waktu respon untuk MySQL mencapai $16.386 / \mathrm{ms}$ sedangkan untuk MariaDB sebesar 25.642/ms.

Percobaan ketiga dilakukan dengan menaikkan jumlah web server yang diakses secara bersamaan sebesar 300 kali namun tetap dengan ketentuan sebanyak 1.000 kali web server diakses. Gambar 4 menunjukkan grafik hasil percobaan ketiga dimana diperoleh bahwa waktu respon web server masih memiliki kinerja yang lebih baik ketika menggunakan RDBMS MySQL dimana waktu responnya sebesar 30.025/ms pada akses ke 1.000 sedangkan ketika menggunakan MariaDB memiliki waktu respon sebesar $40.831 / \mathrm{ms}$.

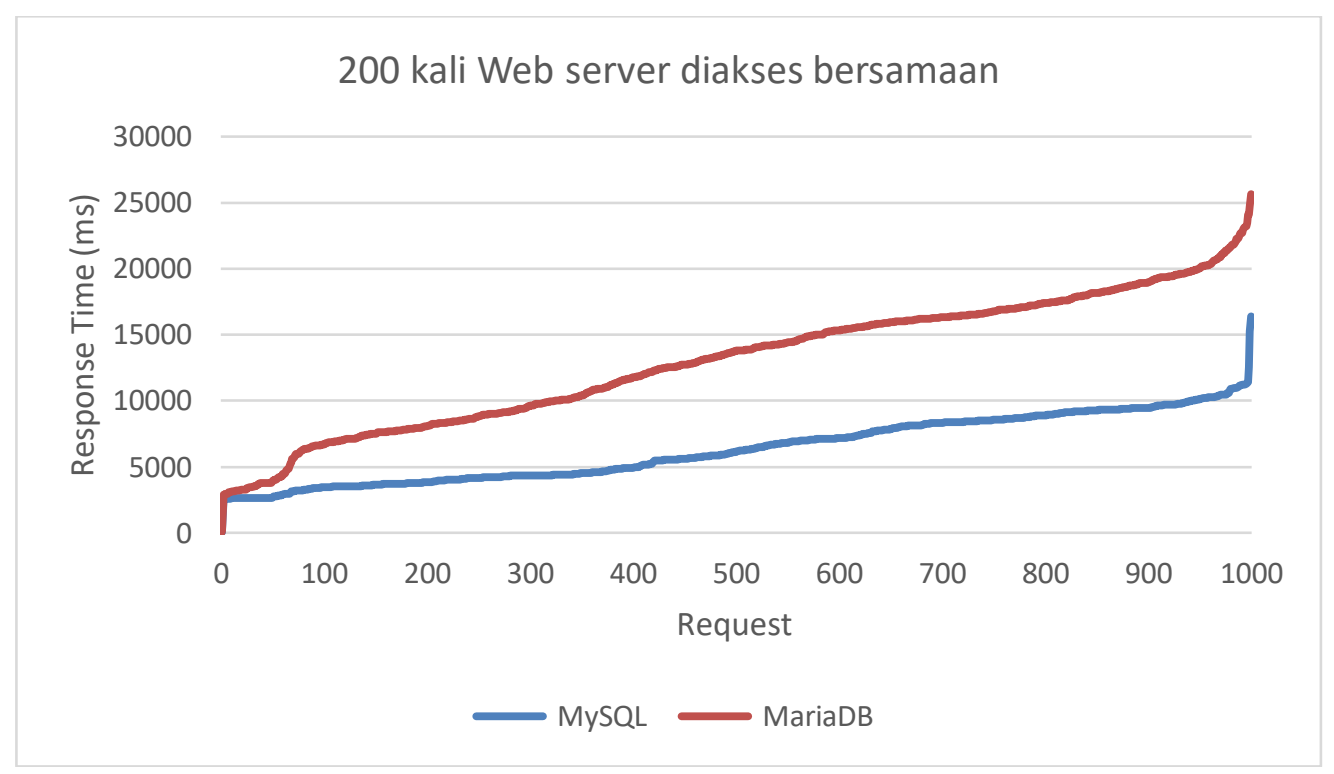

Gbr. 3. Kinerja Web Server 200 kali diakses bersamaan 
Percobaan keempat dilakukan dengan 1.000 kali web server diakses dengan menaikkan kembali jumlah web server diakses secara bersamaan sebesar 400 kali. Dapat dilihat pada Gambar 5 yang menunjukkan bahwa secara keseluruhan web server ketika menggunakan RDBMS MariaDB secara keseluruhan cenderung memperlihatkan kinerja yang lebih baik dibanding MySQL. Dimana MariaDB pada akses ke 1.000 web server memiliki waktu respon sebesar 48.021/ms sedangkan MySQL sebesar 51.877/ms.

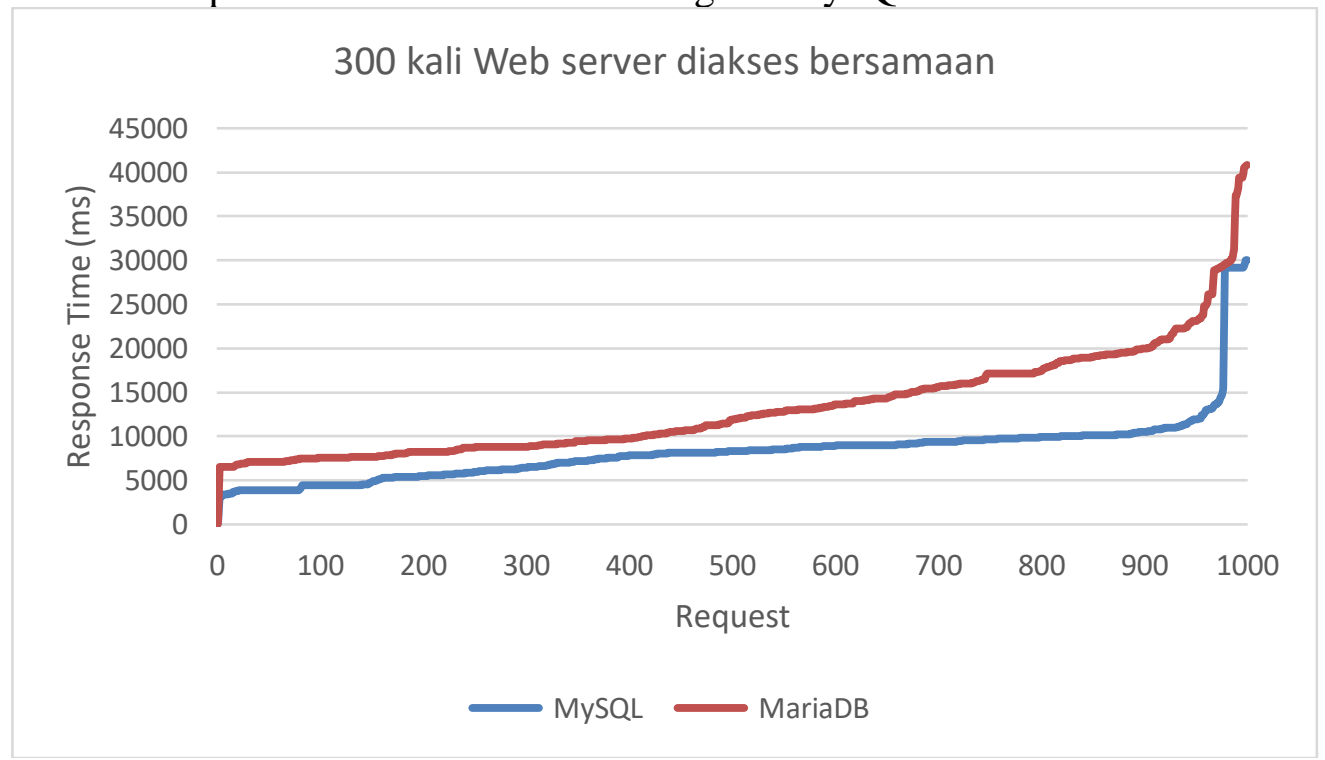

Gbr. 4. Kinerja Web Server 300 kali diakses bersamaan

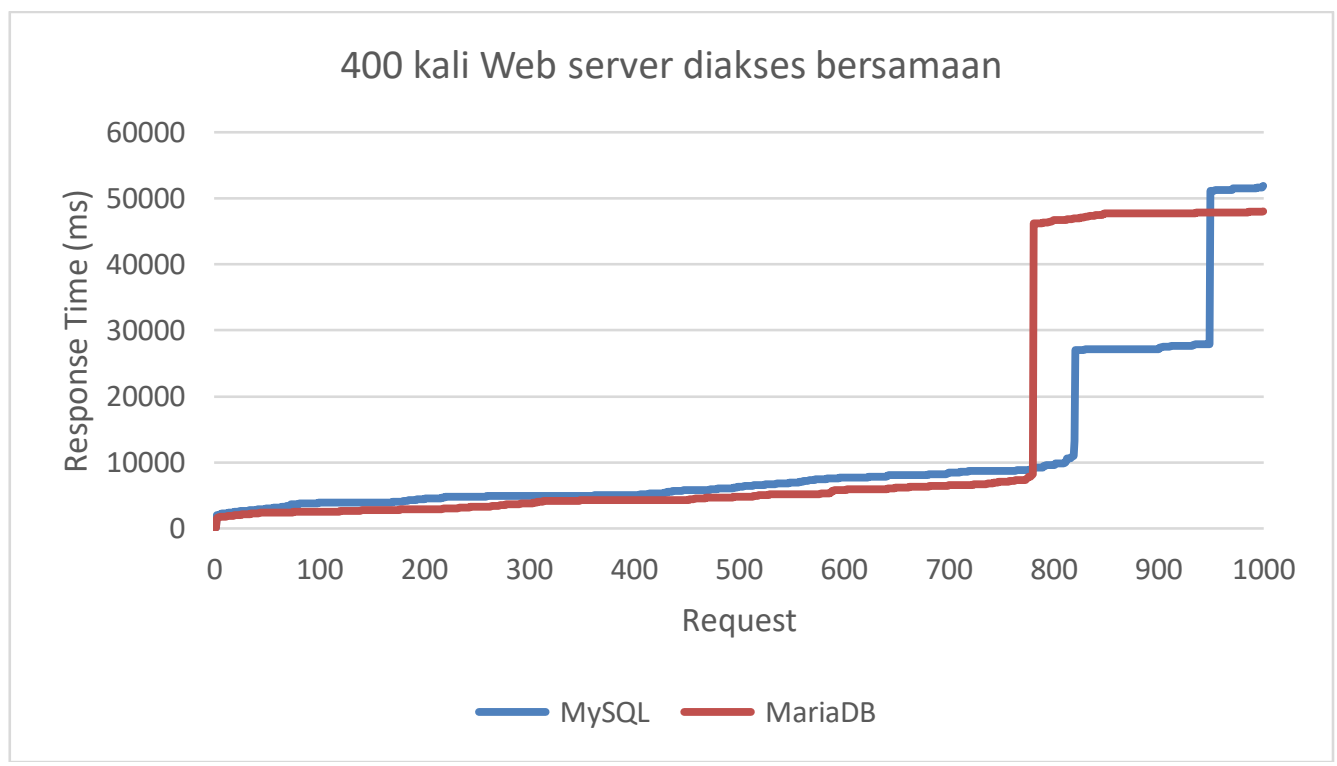

Gbr. 5. Kinerja Web Server 400 kali diakses bersamaan

Selanjutnya dilakukan percobaan terakhir yaitu dengan 1.000 kali web server diakses dengan menaikkan jumlah web server diakses 500 kali secara bersamaan. Hasil percobaan menunjukkan bahwa web server memiliki waktu respon yang cukup baik ketika menggunakan RDBMS MariaDB dibanding dengan MySQL. Dapat dilihat pada gambar 6 dimana waktu respon web server saat diakses di atas 700 cenderung lebih cepat ketika RDBMS MariaDB digunakan. Pada akses ke 1.000 waktu respon sebesar 51.630/ms untuk MariaDB dan 54.702/ms untuk MySQL. 


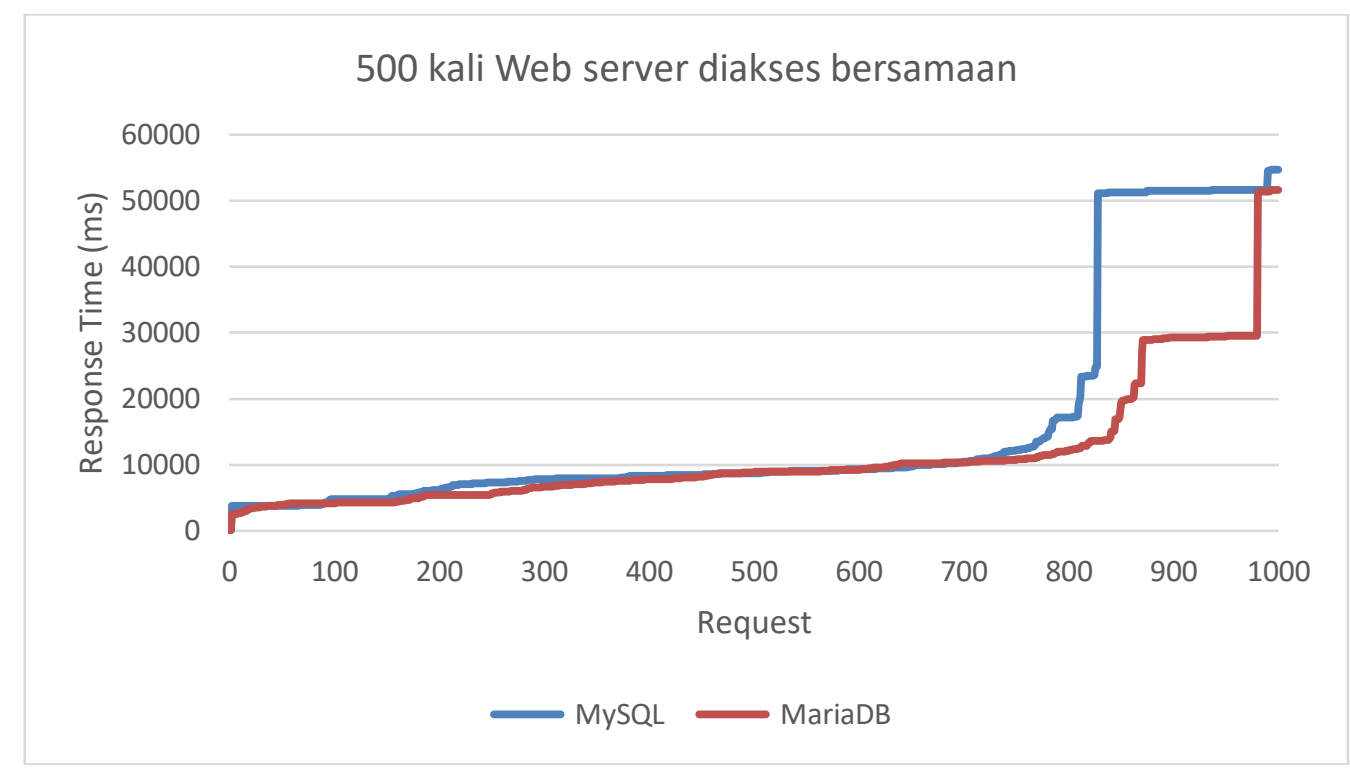

Gbr. 6. Kinerja Web Server 500 kali diakses bersamaan

\section{Kesimpulan}

Tujuan dari penelitian ini adalah untuk mengetahui kinerja waktu respon web server pada Sistem Informasi Manajemen Diklat Poltekpel Sorong ketika menggunakan RDBMS MySQL dan MariaDB. Berdasarkan hasil dan penjabaran percobaan yang telah dilakukan, dapat disimpulkan bahwa web server ketika menggunakan RDBMS MySQL cenderung memiliki performa yang cukup stabil ketika permintaan akses web di bawah 300 kali permintaan secara bersamaan. Namun, saat permintaan akses web di atas 300 secara bersamaan RDBMS MariaDB justru menunjukkan kinerja yang lebih baik. Hal ini ditunjukkan dengan permintaan akses 400 dan 500 kali web server secara bersamaan, waktu respon terlihat lebih cepat dibandingkan ketika menggunakan RDBMS MySQL.

Dari hasil penelitian ini dapat disimpulkan juga bahwa faktor yang mempengaruhi waktu respon sebuah web server juga tergantung pada RDBMS yang digunakan.

\section{Daftar Pustaka}

Aditya, B., \& Juhana, T. (2015). A high availability (HA) MariaDB Galera Cluster across data center with optimized WRR scheduling algorithm of LVS - TUN. 2015 9th International Conference on Telecommunication Systems Services and Applications (TSSA), 1-5. https://doi.org/10.1109/TSSA.2015.7440452

Dawodi, M., Hedayati, M. H., Baktash, J. A., \& Erfan, A. L. (2019). Facebook MySQL Performance vs MySQL Performance. 2019 IEEE 10th Annual Information Technology, Electronics and Mobile Communication Conference (IEMCON), 0103-0109. https://doi.org/10.1109/IEMCON.2019.8936259

Forta, B. (2011). MariaDB Crash Course: MariaDB Crash Course _1. Addison-Wesley Professional.

Fuad, A., Erwin, A., \& Ipung, H. P. (2014). Processing performance on Apache Pig, Apache Hive and MySQL cluster. Proceedings of International Conference on 
Information, Communication Technology and System (ICTS) 2014, 297-302. https://doi.org/10.1109/ICTS.2014.7010600

Kunda, D., Chihana, S., \& Muwanei, S. (2017). Web Server Performance of Apache and Nginx: A Systematic Literature Review. 8, 43-52.

Ongo, G., \& Kusuma, G. P. (2018). Hybrid Database System of MySQL and MongoDB in Web Application Development. 2018 International Conference on Information Management and Technology (ICIMTech), 256-260. https://doi.org/10.1109/ICIMTech.2018.8528120

Pachev, A., \& Pachev, S. (2007). Understanding MySQL internals. O'Reilly.

Rafamantanantsoa, F., \& Laha, M. (2018). Analysis and Neural Networks Modeling of Web Server Performances Using MySQL and PostgreSQL. Communications and Network, 10(4), 142-151. https://doi.org/10.4236/cn.2018.104012

Razzoli, F. (2014). Mastering MariaDB. Packt Publishing Ltd.

Saikia, A., Joy, S., Dolma, D., \& R, R. (2015). Comparative Performance Analysis of MySQL and SQL Server Relational Database Management Systems in Windows Environment. $\quad$ IJARCCE, https://doi.org/10.17148/IJARCCE.2015.4339

Sriparasa, S. S. (2014). Building a Web Application with PHP and MariaDB: A Reference Guide. Packt Publishing Ltd.

Tongkaw, S., \& Tongkaw, A. (2016). A comparison of database performance of MariaDB and MySQL with OLTP workload. 2016 IEEE Conference on Open Systems (ICOS), 117-119. https://doi.org/10.1109/ICOS.2016.7881999

Warman, I., \& Ramdaniansyah, R. (2018). Analisis Perbandingan Kinerja Query Database Management System (Dbms) Antara Mysql 5.7. 16 Dan Mariadb 10.1. Jurnal Teknoif, 6(1).

Watson, R. T., Boudreau, M.-C., York, P. T., Greiner, M. E., \& Wynn, D. (2008). The business of open source. Communications of the ACM, 51(4), 41-46. https://doi.org/10.1145/1330311.1330321

Widenius, M., Axmark, D., AB, M., \& Arno, K. (2002). MySQL Reference Manual: Documentation from the Source. O'Reilly Media, Incorporated. 